University of Nebraska - Lincoln

DigitalCommons@University of Nebraska - Lincoln

Faculty Papers and Publications in Animal

Science

Animal Science Department

1996

\title{
Embryonal Survival to 6 Days in Mice Selected on Different Criteria for Litter Size
}

E. L. de A. Ribeiro

Universidade Estadual de Londrina

M. A. J. van Engelen

Churchillweg 14, 6706 AA Wageningen, The Netherlands

Merlyn K. Nielsen

University of Nebraska-Lincoln, mnielsen1@unl.edu

Follow this and additional works at: https://digitalcommons.unl.edu/animalscifacpub

Part of the Animal Sciences Commons

de A. Ribeiro, E. L.; van Engelen, M. A. J.; and Nielsen, Merlyn K., "Embryonal Survival to 6 Days in Mice Selected on Different Criteria for Litter Size" (1996). Faculty Papers and Publications in Animal Science. 490.

https://digitalcommons.unl.edu/animalscifacpub/490

This Article is brought to you for free and open access by the Animal Science Department at DigitalCommons@University of Nebraska - Lincoln. It has been accepted for inclusion in Faculty Papers and Publications in Animal Science by an authorized administrator of DigitalCommons@University of Nebraska - Lincoln. 


\section{Embryonal Survival to 6 Days in Mice Selected on Different Criteria for Litter Size ${ }^{1}$}

\section{E. L. de A. Ribeiro2,3, M.A.J. van Engelen4, and M. K. Nielsen5}

Department of Animal Science, University of Nebraska-Lincoln, Lincoln 68583-0908

\begin{abstract}
Embryonal survival was compared in mice resulting from four criteria of selection: $\mathrm{LS}=$ selection on number born; IX = selection on an index of ovulation rate and ova success; UT = selection on number born to unilaterally ovariectomized females; and LC = unselected control. Selection occurred for 21 generations with three replicates of the four criteria; thereafter, relaxed selection was practiced. The evaluation was performed using mice of two replicates at Generation 35 and one replicate at Generation 36. Data on a total of 289 female mice were recorded. Females, at an average age of $9 \mathrm{wk}$, were mated to males of the same line. Six days after mating, each female was killed, ovaries were excised, corpora lutea were counted and equated to number of ova shed, and
\end{abstract}

the numbers of implantation sites in each uterine horn were recorded. Least squares means were .84, .91, .85, and .82 for left embryonal survival (left implantations/left ova) and .91, .90, .86, and .87 for right embryonal survival for LS, IX, UT, and LC, respectively. The right side had greater ovulation rate $(\mathrm{P}<$ $.001)$ and number of implantations $(P<.001)$. For embryonal survival, the criterion $\times$ side interaction was possibly important $(P<.09)$. Selection for litter size by different criteria increased ovulation rate ( $P<$ $.003)$ and embryonal survival $(P<.05)$ to $6 \mathrm{~d}$. However, responses in embryonal survival were not greater after UT selection compared with LS or IX selection.

\section{Key Words: Mice, Selection, Litter Size, Embryos}

\section{Introduction}

Realized litter size at birth depends on several components. Litter size has been successfully increased through direct selection on increased number born (Falconer, 1960; J oakimsen and Baker, 1977; Bakker et al., 1978; Eisen, 1978; Kirby and Nielsen, 1993) or on its components: ovulation rate ( $L$ and and Falconer, 1969), prenatal survival (Bradford, 1969, 1979), uterine capacity (Kirby and Nielsen, 1993), and an index of components (Kirby and Nielsen, 1993).

Response to selection for increased litter size is realized in part through an increase in number of ova

\footnotetext{
${ }^{1}$ Published as paper no. 11198, J ournal Ser., Nebraska Agric. Res. Div., Univ. of Nebraska, Lincoln 68583-0908.

${ }^{2}$ Current address: Departamento de Zootecnia, Universidade Estadual de Londrina, Londrina-PR, 86051-970, Brazil.

3 Supported by Consel ho Nacional de Desenvolvimento Cientifico e Tecnologico (CNPq), Brazil.

${ }^{4}$ Current address: Churchillweg 14, 6706 AA Wageningen, The Netherlands.

5To whom correspondence should be addressed: A218 Animal Science.

Received J uly 7, 1995.

Accepted November 3, 1995.
}

shed (Falconer, 1960; J oakimsen and Baker, 1977; Bakker et al., 1978). Bakker et al. (1978) also observed an improvement in survival before and after implantation. Direct selection for ovulation rate usually has increased number of ova shed, but litter size does not increase proportionally and has not always increased. This is due to a concomitant increase in prenatal mortality (Bradford, 1969; Land and Falconer, 1969). This may result from uterine capacity not increasing along with ovulation rate, and hence a lower proportion of embryos survive.

By d 6 of gestation, mouse embryos have already implanted in the uterus. Losses at $6 \mathrm{~d}$, relative to number of ova shed, would include all losses due to nonviable embryos and perhaps already some of the those due to the limitations of uterine capacity. The specific objective of this work was to determine whether lines of mice that differ in ovulation rate and litter size also differ in embryonal survival to $6 \mathrm{~d}$.

\section{Materials and Methods}

Source of Mice. The mice came from a selection experiment conducted at the University of NebraskaLincoln. The four criteria of selection were as follows: 
1) IX: Selection on an index that included ovulation rate and ova success (the ratio of total number of pups born to ovulation rate) as suggested by J ohnson et al. (1984); 2) UT: Selection on number born to unilaterally ovariectomized females, intended as selection for uterine capacity as described by Christenson et al. (1987); 3) LS: Selection on total number born; and 4) LC: Unselected control.

Each criterion was replicated three times, resulting in 12 distinct lines. The three replicates were separated by 4 wk. Selection was practiced for 21 generations, and afterward relaxed selection was practiced. Implementation of selection methods was described by Clutter et al. (1990), and selection results for Generations 5 and 13 were published by Gion et al. (1990) and for Generation 21 plus six subsequent generations of relaxed selection by Kirby and Nielsen (1993). At Generation 21, mean litter sizes in the selected lines, deviated from the control, were 4.09, 3.17, and 1.67 for LS, IX, and UT, respectively (Kirby and Nielsen, 1993). No changes have been observed in litter size during the generations of relaxed selection. Mean ovulation rates in the selected lines, deviated from the control, at Generation 27 were 3.9 (LS), 2.7 (IX), and 1.6 (UT) ova (AIShorepy et al., 1992). In the experiment, 289 female mice from Replicates 2 and 3 of Generation 35 and from Replicate 1 of Generation 36 were used.

Animal Management and Data Collection. Mice were housed in rooms with temperature maintained at approximately $24^{\circ} \mathrm{C}$, and the lighting was controlled to provide $12 \mathrm{~h}$ of light daily. Mice had ad libitum access to water and feed (Diet 8604, Harlan Teklad, Madison, WI ).

In each replicate, virgin females were mated to males of their same lines at an average age of $9 \mathrm{wk}$, in a proportion of 3:1, respectively. Matings were assigned to minimize inbreeding. Females were checked daily, starting at 0800 in the morning, for mating plugs. The day a mating plug was first observed was set as $d 0$. Six days later, the female was killed by cervical dislocation and traits were recorded. The ovaries were excised, and corpora lutea were counted under magnification (10x) to estimate ovulation rate. The uterine horns were exposed, and the number of implantation sites was recorded for each side of the uterus. Left embryonal survival to $6 \mathrm{~d}$ was estimated by the ratio of left implantation sites to left ovulation rate (number of corpora lutea); estimates for the right side were calculated by the same method. Measurement of embryonal survival was made at d 6 after mating because implantation sites can be easily counted, and uterine capacity was expected to have little or no effect on losses. The losses occurred in the periods just before and just after implantation. According to Bolet (1986), the preimplantation period, with changes in blastocyst development and embryonal migration before attachment, is the most critical and when most losses occur.
Statistical Analyses. Ovulation rate, number of implantation sites, and embryonal survival to $6 \mathrm{~d}$ were analyzed with the method of least squares (GLM procedure of SAS, 1989) using the same statistical model. The model included the fixed effects of selection criterion and side of the reproductive tract, the random effect of replicate, and all possible two- and three-way interactions. The effect of side was removed from the model for analyses of total ovulation rate, total implantation sites, and total embryonal survival to $6 \mathrm{~d}$. Phenotypic residual correlations were pooled within replicate-selection criterion classes.

Replicate, criterion of selection, and the interaction between them were the main-plot terms in the analysis of variance. The effect of criterion of selection was tested with the interaction of replicate $\times$ selection criterion as the error term. Mice were the subplot experimental units. Side of the reproductive tract was tested using the subplot residual (mice/replicateselection criterion-side) source of variation as the error term. The interaction of side of the reproductive tract $\times$ criterion of selection was tested using the interaction of side $\times$ replicate $\times$ selection criterion.

The three degrees of freedom for selection criteria were separated into three orthogonal contrasts. The contrasts were assigned to 1 ) test the general effect of selection, 2) compare the effect of selection for litter size to that of uterine capacity (a component of litter size), and 3) compare the usual selection for litter size with that of an index. The contrasts were mean of LS, IX, and UT VS LC; mean of LS and IX Vs UT; and LS vs IX, respectively.

Because embryonal survival to $6 \mathrm{~d}$ (ratio of implantation sites [EMB] to ovulation rate [OR]) averaged greater than .85 , it was transformed by a logit function (Cox, 1970) as follows:

$$
\text { Lgt }=\log _{e}\left[\frac{E M B+\frac{1}{2}}{O R-E M B+\frac{1}{2}}\right] \text {, }
$$

where Lgt is the dependent variable used in the analyses of variance. To avoid undefined results (i.e., zeros in the denominator), the fraction $1 / 2$ was added to both the numerator and denominator. Least squares means of the Lgt were retransformed to means of embryonal survival to $6 \mathrm{~d}$ (ES) with the function:

$$
E S=\left[\frac{1}{1+e^{-L g t}}\right]
$$

\section{Results}

Significance of contrasts and least squares means for ovulation rate, number of implantation sites, and embryonal survival to $6 \mathrm{~d}$ are presented by criterion in 
Table 1. Least squares means $( \pm \mathrm{SE})$ and contrasts for four selection criteria for ovulation rate, implantation sites, and embryonal survival to 6 days

\begin{tabular}{|c|c|c|c|c|c|c|c|}
\hline \multirow[b]{3}{*}{ Trait $^{\mathrm{a}}$} & \multirow{2}{*}{\multicolumn{4}{|c|}{ Selection criterion ${ }^{\mathrm{b}}$ means }} & \multicolumn{3}{|c|}{ Contrast significance level } \\
\hline & & & & & \multirow{2}{*}{$\begin{array}{l}\text { LS, IX, UT } \\
\text { vs LC }\end{array}$} & \multirow{2}{*}{$\begin{array}{l}\text { LS, IX } \\
\text { Vs UT }\end{array}$} & \multirow[b]{2}{*}{ LS vs IX } \\
\hline & LS & IX & UT & LC & & & \\
\hline LOR & $8.35 \pm .34$ & $8.16 \pm .32$ & $7.24 \pm .33$ & $6.37 \pm .36$ & .01 & .04 & .68 \\
\hline ROR & $9.95 \pm .34$ & $8.87 \pm .32$ & $7.65 \pm .33$ & $7.34 \pm .36$ & .02 & .01 & .08 \\
\hline TOR & $18.30 \pm .50$ & $17.03 \pm .48$ & $14.89 \pm .49$ & $13.71 \pm .54$ & .003 & .004 & .12 \\
\hline LEMB & $6.83 \pm .37$ & $7.59 \pm .35$ & $6.13 \pm .36$ & $5.20 \pm .40$ & .02 & .07 & .22 \\
\hline REMB & $9.05 \pm .37$ & $8.19 \pm .35$ & $6.51 \pm .36$ & $6.38 \pm .40$ & .02 & .003 & .13 \\
\hline TEMB & $15.88 \pm .55$ & $15.79 \pm .52$ & $12.64 \pm .53$ & $11.59 \pm .58$ & .003 & .003 & .90 \\
\hline $\mathrm{LES}^{\mathrm{C}}$ & $\begin{array}{c}1.64 \pm .11 \\
(.84)\end{array}$ & $\begin{array}{c}2.26 \pm .11 \\
(.91)\end{array}$ & $\begin{array}{c}1.70 \pm .11 \\
(.85)\end{array}$ & $\begin{array}{c}1.48 \pm .12 \\
(.82)\end{array}$ & .05 & .15 & .01 \\
\hline RES $^{\mathrm{C}}$ & $\begin{array}{c}2.27 \pm .11 \\
(.91)\end{array}$ & $\begin{array}{c}2.23 \pm .11 \\
(.90)\end{array}$ & $\begin{array}{c}1.81 \pm .11 \\
(.86)\end{array}$ & $\begin{array}{c}1.88 \pm .12 \\
(.87)\end{array}$ & .13 & .02 & .82 \\
\hline TES $^{\mathrm{C}}$ & $\begin{array}{c}2.18 \pm .11 \\
(.90)\end{array}$ & $\begin{array}{c}2.57 \pm .11 \\
(.93)\end{array}$ & $\begin{array}{c}1.99 \pm .11 \\
(.88)\end{array}$ & $\begin{array}{c}1.90 \pm .12 \\
(.87)\end{array}$ & .05 & .03 & .05 \\
\hline
\end{tabular}

${ }^{a}$ LOR, ROR, TOR = left, right, and total ovulation rates, respectively; LEMB, REMB, TEMB = left, right, and total implantation sites, respectively; LES, RES, TES = left, right, and total embryonal survivals, respectively.

$\mathrm{b}_{\mathrm{LS}}=\mathrm{Litter}$ size, IX = index selection, UT = uterine capacity, and LC = unselected control.

CAnalyzed as logit. Retransformed probabilities in parentheses.

Table 1. The effect of the interaction criterion $\times$ side was not important for ovulation rate ( $P>.40)$, and for number of implantation sites and embryonal survival to $6 \mathrm{~d}$, the probability values were .15 and .09, respectively. The effects of criteria and side were significant $(P<.01$ and $P<.001$, respectively) for all three traits.

The right side of the reproductive tract consistently had more ovulations and implantation sites than the left side ( 8.45 vs 7.53 and 7.53 vs 6.44 , respectively). However, embryonal survival did not have this same trend for all selection criteria. Left and right embryonal survival were almost the same in the IX and UT. In fact, the left side of IX mice had a small advantage over the right side (.91 vs .90).

Selection (LS, IX, UT vs LC) had a positive effect $(\mathrm{P}<.003$ to $\mathrm{P}<.05)$ on all traits except right embryonal survival ( $P=.13$ ). Selection for uterine capacity did not improve the traits studied when compared with selection for litter size (LS, IX vs UT). Means for LS and IX were greater than means for UT. Probability values varied from .003 for right and total number of implantation sites to .15 for left embryonal survival. The LS and IX were similar in several traits: left ovulation rate, left and total implantation sites, and right embryonal survival. The LS tended to have greater means for right ovulation rate $(P<.08)$, total ovulation rate $(P<.12)$, and right implantation sites $(\mathrm{P}<.13)$, but conversely the IX had greater left $(\mathrm{P}<$ $.01)$ and total embryonal survival $(P<.05)$.

Phenotypic correlations pooled within replicateselection criterion classes are presented in Table 2. Ovulation rate on one side of the reproductive tract was strongly positively correlated with number of implantation sites on the same side (.74 and .77 for left and right sides, respectively). However, correlations between left and right ovulation rates and left and right implantation sites were less and negative

Table 2. Phenotypic correlations between ovulation rate, implantation sites, and embryonal survival to 6 days ${ }^{\mathrm{a}}$

\begin{tabular}{lccccrrrr}
\hline \hline Trait $^{b}$ & ROR & TOR & LEMB & REMB & TEMB & LES & RES & TES \\
\hline LOR & -.45 & .51 & .74 & -.45 & .24 & .08 & -.19 & -.10 \\
ROR & & .54 & -.38 & .77 & .30 & -.13 & .05 & -.07 \\
TOR & & & .33 & .32 & .52 & -.05 & -.13 & -.16 \\
LEMB & & & & -.21 & .64 & .70 & .08 & .45 \\
REMB & & & & & .61 & .10 & .65 & .41 \\
TEMB & & & & & & .57 & .29 & .69 \\
LES & & & & & & & .76 \\
RES & & & & & & & & .71 \\
\hline
\end{tabular}

apooled within replicate-selection criterion classes. Correlations (absolute values) equal or greater than .16 had probability levels of at least .01. Correlations (absolute values) equal or less than .08 were not significant $(\mathrm{P}>.16$ to $\mathrm{P}>.44)$.

$\mathrm{b}_{\mathrm{LOR}}, \mathrm{ROR}, \mathrm{TOR}=$ left, right, and total ovulation rates, respectively; LEMB, REMB, TEMB = left, right, and total implantation sites, respectively; LES, RES, TES = left, right, and total embryonal survivals, respectively. 
( -.45 and -.21 , respectively). Left and right embryonal survival seems to be independent of left and right ovulation rate; the correlations were small and positive, .08 and .05, respectively, for left and right sides. Correlations between left ovulation rate and right embryonal survival, and between right ovulation rate and left embryonal survival, were relatively small and negative (-.19 and -.13 , respectively). In contrast, number of implantation sites was highly and positively correlated with embryonal survival (.70 and .65 for left and right sides, respectively). In the same way, the total number of implantation sites had a high positive correlation with total embryonal survival (.69) and with total ovulation rate (.52). The correlation between total embryonal survival and total ovulation rate followed the ones between sides, being relatively small and negative (-.16).

\section{Discussion}

After 14 generations of relaxed selection, the advantages of the selected lines over the control for ovulation rate were maintained. The LS, IX, and UT selection criteria produced 4.59, 3.32, and 1.18, respectively, more ova than the control, and these differences agree well with results reported for Generation 27 by Al-Shorepy et al. (1992). Direct responses to selection based on ovulation rate have been reported (Land and Falconer, 1969; Bradford, 1969, 1979), as well as a correlated response to selection on number born (Falconer, 1960; J oakimsen and Baker, 1977; Bakker et al., 1978; Bradford, 1979).

Some causes for the increase of ovulation rate due to selection have been suggested. Land and Falconer (1969) observed that the increase in ovulation rate after selection for high natural ovulation was due to an increase in FSH activity. Durrant et al. (1980) commented that the increased ovulation rate in lines of mice selected for large litter size or for large body size could possibly be explained by enhanced ovarian sensitivity to gonadotropins. Ovarian weights were also increased independently of body weight in the line selected for large litter size (Durrant et al., 1980).

The superiority of the right side in ovulation rate was also maintained, ranging in this study from .41 ovum in the UT to 1.6 ova in the LS. Al-Shorepy et al. (1992) also found the smallest difference between sides in the UT selection (.84). Perhaps this has to do with the implementation of selection on this criterion (Clutter et al., 1990), where the right ovary was excised and consequently all the direct selection pressure occurred on the left side of the reproductive tract.

Greater ovulation rate for the right ovary is consistent with the literature (Falconer et al., 1961; McLaren, 1963; Wiebold and Becker, 1987). On the basis of a literature review, Wiebold and Becker (1987) suggested several possible causes for the differences in ovulation rate between sides. These causes include differences in follicular pools, ovarian blood flow, vagal innervation, and larger number of gonadotropin receptors.

The negative correlation (-.45) between left and right ovulation rate is of the same magnitude as the one (-.44) reported by Bowman and Roberts (1958) and is in the range reported by Falconer et al. (1961) and MCLaren (1963). The correlation in the base generation of this experiment was -.51 (Clutter et al., 1990).

The number of implantation sites at $d 6$ of pregnancy followed the same pattern as ovulation rate; selection had an overall positive effect on number of implantation sites. Within side, ovulation rate and implantation sites were highly correlated (.74 and .77 for left and right sides, respectively). The difference between LS and IX in total implantation sites was minimal (.09) and not significant. This difference is less than the one for ovulation rate $(1.27, \mathrm{P}<.12)$ and was due to comparatively fewer left implantation sites in the LS selection. We do not have any explanation for how this happened.

Because the correlation between sides for ovulation rate was negative and implantation sites were proportional to ovulation rate, a negative correlation $(-.21)$ between left and right implantation sites was expected. The same was reported by Bowman and Roberts (1958) and by McLaren (1963) for implantation sites counted at later stages of gestation (16 to 19 d). However, in the base generation of this experiment, Clutter et al. (1990) reported a phenotypic correlation between sides for number of fetuses at $d 17$ of gestation of -.01 , which was not different from zero.

The observation made by Bowman and Roberts (1958), with mice of heterogeneous origin, that a proportionately greater loss of ova was observed in uterine horns that received greater numbers of ova, and by J ohnson et al. (1984) that sows with greater ovulation rate have greater embryonal losses, was partially observed here. The correlation between total ovulation rate and total embryonal survival, although small $(-.16)$, was significant $(P<.01)$. However, the correlation within side was small and not significant (.08 and .05 for left and right sides, respectively).

Selection had a positive effect on total embryonal survival until d 6 after mating; the mean for the three selected criteria was greater than the mean for the control. Other selection experiments, in which the criterion was total number born, also produced an improvement in embryonal survival (Bakker et al., 1978; Bradford, 1979). Durrant et al. (1980) did not observe an improvement in embryonal survival at an early stage of gestation (d 2 after mating) in a line selected for litter size compared with a control line, but embryonal survival measured between $\mathrm{d} 7$ and 16 
improved in the selected line. However, other experiments have not produced any improvement in embryonal survival, as reported by Falconer (1960), Bradford (1969), and J oakimsen and Baker (1977).

Several causes for embryonal losses before and after implantation have been evaluated or suggested in the literature. Some of them are lack of fertilization (Bowman and Roberts, 1958; Falconer, 1960), crowding of the uterine horn (Bowman and Roberts, 1958; Webel and Dziuk, 1974), inbreeding depression (F alconer, 1960), rate of development of ova or embryos (Gates, 1965; Durrant et al., 1980; Moler et al., 1980; Golbard and Warner, 1982), concentrations of progesterone (Michael et al., 1975; Wilmut et al., 1986), maternal-uterine environment (Moler et al., 1980; Durrant et al., 1980), and other environmental effects such as age, feeding, season, and temperature as cited by Bolet et al. (1986) and Wilmut et al. (1986).

Some of the factors cited above were previously evaluated in this population of mice. The accumulated inbreeding at Generation 27 was similar among criteria (Kirby and Nielsen, 1993) and is not expected to be a cause for the differences. The most reasonable explanation for the increased embryonal survival in the selected lines is the faster and more uniform embryonic development, as evaluated at Generation 27 by Al-Shorepy et al. (1992), and also a greater uterine capacity, as evaluated at Generations 22 and 23 by Clutter et al. (1994). Uterine capacity was defined as all factors related to the dam affecting the embryos after they enter the uterus. However, we do not know whether uterine capacity limitations have already started affecting embryonal survival at this stage (d 6) of gestation.

Selection for litter size (the average of LS and IX) increased embryonal survival more than direct selection for uterine capacity (UT). Although embryonic development did not differ between LS and IX in Generation 27 (AL-Shorepy et al., 1992), uterine capacity tended to be different in Generations 22 and 23 (Clutter et al., 1994). The difference between LS and IX in total embryonal survival was due mainly to a comparatively low left embryonal survival in the LS; as mentioned before, we have no explanation for how this happened.

An observed advantage of the right side over the left side in embryonal survival is clear in the LS and LC, but this did not happen with the IX and UT. AIShorepy et al. (1992) did not report clear differences between sides for embryonic development; however, Clutter et al. (1994) reported an advantage of the right uterine capacity for all criteria. Advantage of the right side in embryonal survival was reported by MCLaren (1963). Wiebold and Becker (1987) also reported greater embryonal survival in the right side of embryo-transfer recipients; however, this did not happen in mice with natural pregnancies. Durrant et al. (1980) also did not find any difference between sides.

\section{Implications}

Selection for litter size increases embryonal survival to $6 \mathrm{~d}$ in mice. Increases in ovulation rate, early embryonal survival, uterine capacity, or any combination will result in an increase in litter size.

\section{Literature Cited}

Al-Shorepy, S. A., A. C. Clutter, R. M. Blair, and M. K. Nielsen. 1992. Effects of three methods of selection for litter size in mice on pre-implantation embryonic development. Biol. Reprod. 46: 958.

Bakker, H., J. H. Wallinga, and R. D. Politiek. 1978. Reproduction and body weight of mice after long-term selection for large litter size. J. Anim. Sci. 46:1572.

Bolet, G. 1986. Timing and extent of embryonic mortality in pigs, sheep and goats: Genetic variability. In: J . M. Sreenan and M. G. Diskin (ed.). Embryonic Mortality in Farm Animals. pp 12-43. Martinus Nijhoff Publishers, Dordrecht, The Netherlands.

Bowman, J. C., and R. C. Roberts. 1958. Embryonic mortality in relation to ovulation rate in the house mouse. J . Exp. Biol. 35: 138.

Bradford, G. E. 1969. Genetic control of ovulation rate and embryo survival in mice. I. Response to selection. Genetics 61:905.

Bradford, G. E. 1979. Genetic variation in prenatal survival and litter size. Proc. XIII Biennial Symp. on Reprod. J. Anim. Sci. 49(Suppl. 2):66.

Christenson, R. K., K. A. Leymaster, and L. D. Young. 1987. J ustification of unilateral hysterectomy-ovariectomy as a model to evaluate uterine capacity in swine. J. Anim. Sci. 65:738.

Clutter, A. C., Y. L. Kochera Kirby, and M. K. Nielsen. 1994. Uterine capacity and ovulation rate in mice selected 21 generations on alternative criteria to increase litter size. J . Anim. Sci. 72:577.

Clutter, A. C., M. K. Nielsen, and R. K. J ohnson. 1990. Alternative methods of selection for litter size in mice: I. Characterization of base population and development of methods. J . Anim. Sci. 68:3536.

Cox, D. R. 1970. Analysis of Binary Data. Chapman and Hall Ltd, London.

Durrant, B. S., E. J . Eisen, and L. C. Ulberg. 1980. Ovulation rate, embryo survival and ovarian sensitivity to gonadotrophins in mice selected for litter size and body weight. J . Reprod. Fertil. 59:329.

Eisen, E. J . 1978. Single-trait and antagonistic index selection for litter size and body weight in mice. Genetics 88:781.

Falconer, D. S. 1960. The genetics of litter size in mice. J. Cell. Comp. Physiol. 56(Suppl. 1):153.

Falconer, D. S., R. G. Edwards, R. E. Fowler, and R. C. Roberts. 1961. Analysis of differences in the number of eggs shed by the two ovaries of mice during natural oestrus or after superovulation. J. Reprod. Fertil. 2:418.

Gates, A. H. 1965. Rate of ovular development as a factor in embryo survival. In: G.E.W. Wolstenholme and M. O'Connor (ed.). Preimplantation Stages of Pregnancy. Little, Brown and Company, Boston, MA.

Gion, J. M., A. C. Clutter, and M. K. Nielsen. 1990. Alternative methods of selection for litter size in mice: II. Response to thirteen generations of selection. J. Anim. Sci. 68:3543.

Goldbard, S. B., and C. M. Warner. 1982. Genes affect the timing of early mouse embryo development. Biol. Reprod. 27:419. 
J oakimsen, O., and R. L. Baker. 1977. Selection for litter size in mice. Acta Agric. Scand. 27:301.

J ohnson, R. K., D. R. Zimmerman, and R. J . Kittok. 1984. Selection for components of reproduction in swine. Livest. Prod. Sci. 11: 541.

Kirby, Y. K., and M. K. Nielsen. 1993. Alternative methods of selection for litter size in mice: III. Response to 21 generations of selection. J. Anim. Sci. 71:571.

Land, R. B., and D. S. Falconer. 1969. Genetic studies of ovulation rate in the mouse. Genet. Res. 13:25.

MCLaren, A. 1963. The distribution of eggs and embryos between sides in the mouse. J. Endocrinol. 27:157.

Michael, S. D., I. I. Geschwind, G. E. Bradford, and G. H. Stabenfeldt. 1975. Pregnancy in mice selected for small litter size:
Reproductive hormone levels and effect of exogenous hormones. Biol. Reprod. 12:400.

Moler, T. L., S. E. Donahue, G. B. Anderson, and G. E. Bradford. 1980. Effects of maternal and embryonic genotype on prenatal survival in two selected mouse lines. J. Anim. Sci. 51:300.

SAS. 1989. SAS/STAT ${ }^{\circledR}$ User's Guide. SAS Inst. Inc., Cary, NC.

Webel, S. K., and P. J . Dziuk. 1974. Effect of stage of gestation and uterine space on prenatal survival in the pig. J. Anim. Sci. 38: 960.

Wiebold, J . L., and W. C. Becker. 1987. Inequality in function of the right and left ovaries and uterine horns of the mouse. J. Reprod. Fertil. 79:125.

Wilmut, I., D. I. Sales, and C. J. Ashworth. 1986. Maternal and embryonic factors associated with prenatal loss in mammals. J . Reprod. Fertil. 76:851. 